\title{
A new locality of expansive moss species Orthodicranum tauricum (Bryophyta, Dicranaceae) in North-Estern Poland
}

Jarosław Chmielewski

\begin{abstract}
A new locality of expansive moss species Orthodicranum tauricum (Bryophyta, Dicranaceae) in
\end{abstract} North-Estern Poland. - Acta Mus. Siles. Sci. Natur., 64: 21-22, 2015.

\begin{abstract}
A new locality of expansive moss species Orthodicranum tauricum has been found in the Napiwodzko - Ramucka forest, between villages Zginłocha and Nowa Kaletka, Poland.
\end{abstract}

Key words: Orthodicranum tauricum, moss, Napiwodzko - Ramucka forest, Poland.

\section{Introduction}

Orthodicranum tauricum (Sapjegin) Smirnova is a species of Atlantis climat zone. In recent times have been observed to increase its range eastward in subcontinental climat zone. In Poland it fund in western Carpathians: Sanocko - Turczańskie mountains, Pogórze Leskie (Ochyra \& Stebel 2008), and NW Poland: Napiwodzko - Ramucka Forest, „Źródła rzeki Łyny" reserve (Pisarek et al. 2002), Napiwodzo - Ramucka Refuge (Sawicki et al. 2013). A new locality was found during performing research in $\mathrm{PhD}$ thesis. O. tauricum significantly increases its reach to the east of the continent. It a species of the Atlantic climate, in which clearly observed on the eastern border of the expansion range of distribution. Probably be binding it with a progressive acidification of microhabitats.

Orthodicranum tauricum is similar to Dicranum viride. Both species are characterized by erect and straight leaves, with fragile upper leaves. But O. tauricum have elongate lamina cells, costa in basal portion lacking stereids bands, with up to $1-2$ cell layers above and below guide cells (Hedenäs et al. 2003, Plášek 2013).

Orthodicranum tauricum occurs mainly on tree bases and bark of trees, rarely is known from rotten wood or soil (Hedenäs et al. 2003).

\section{Description of the new locality}

Locality: Poland, in the municipality Purda, county Olsztyn in Warmia - Mazury on the bark Quercus robur growing along the road 598 connecting Zgniłocha village and Nowa Kaletka village; GPS: $\mathrm{N}=53^{\circ} 32^{\prime} 901^{\prime \prime}, \mathrm{E}=020^{\circ} 35^{\prime} 436^{\prime \prime}$, leg. J. Chmielewski 13.11.2014.

\section{Discussion}

Trees where Orthodicranum tauricum was found its 120 years of oak stem, growing along the provincial road running through a more compact forest complex of Napiwodzko Ramucka Forest. Around trees there is no dense undergrowth, stumps are not so strong shading. In addition, the trees grow inclined towards the roadway, which can affect the conditions microhabitat bark. O. tauricum was accompanied by Hypnum cupressiforme and Orthodicranum montanum. This new locality seems to be the most eastern in the distribution range of this species.

In Poland this species still is spreads. Orthodicranum tauricum occurs mainly on bark of trees and shrubs, such as Betula pendula, Alnus glutinosa and Quercus robur. In Poland, this species it was found also on trees species like Abies alba, Betula pubescens, Larix decidua and Pseudotsuga menziesii (Stebel et al. 2012). It prefers damp forest patches and trees 
growing near lakes, ponds or streams (Stebel et al. 2012) but sometimes inhabits a lonely old trees, growing along forest roads where there is openwork light, which indicates a partially synanthropic nature of the species (Piwowarski 2014). In recent years, the populations of $O$. tauricum also increased in Hungary. Also visible is a progressive expansion to the east the Caucas, forest-steppe and steppe zones of European Russia and hemiboreal zone near Moscow (Stebel et al. 2012).

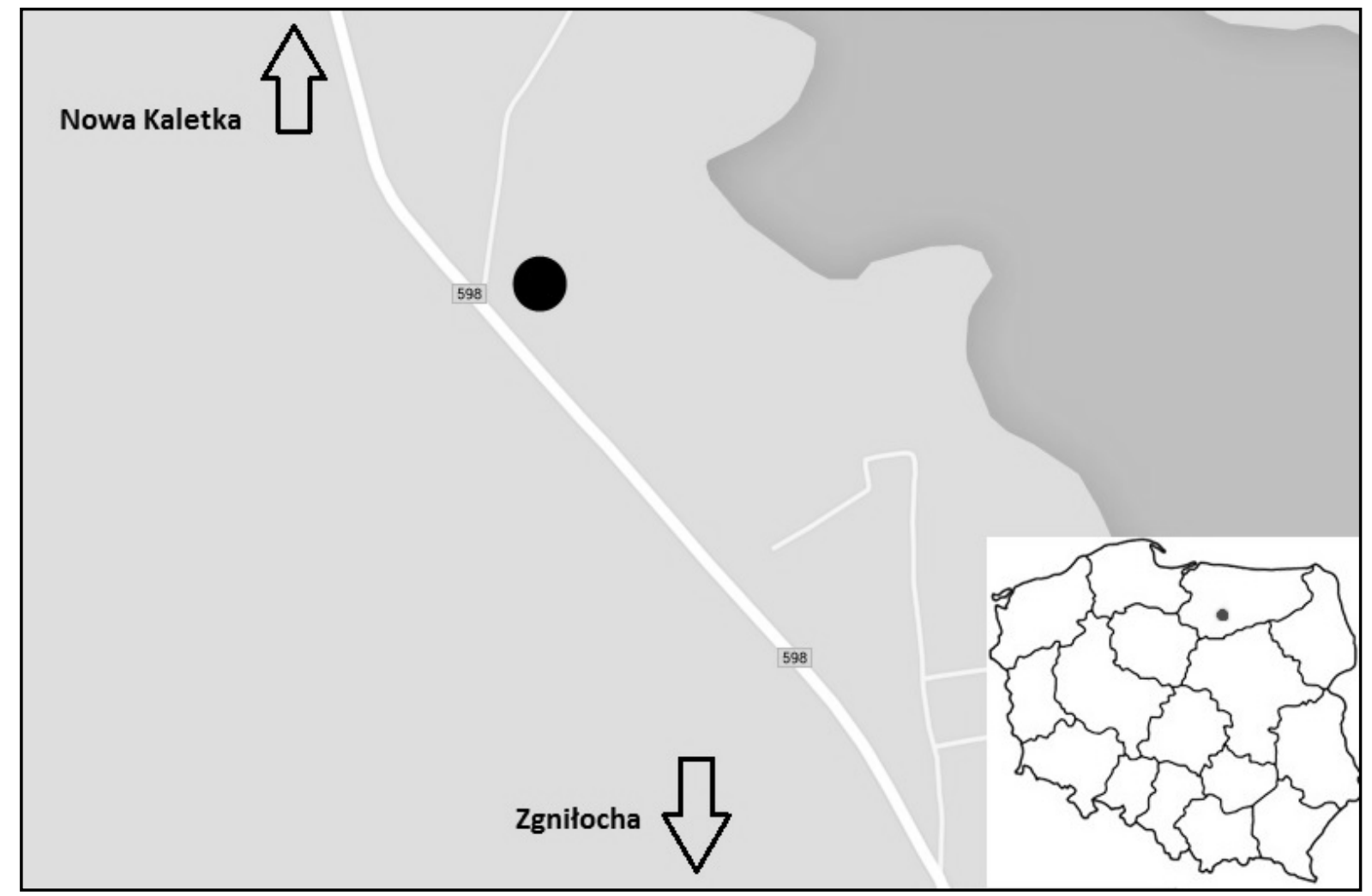

Fig 1: The most eastern locality of Orthotricranum tauricum in Poland

\section{References}

Hedenäs L. \& Bisang I. (2003): Key to European Dicranum species. Swedish Museum of Natural History, Department of Cryptogamic Botany. Stockholm, Sweden.

Pisarek W., Sawicki J. \& Szczecińska M. (2002): Flora of vascular plants and bryophytes of „The head waters the Łyna River dedicated to prof. Kobendza`s reserve. - Acta Botanica Warmiae et Masuriae 2: 93110.

Piwowarski B. (2014): Nowe stanowiska ekspansywnych gatunków mchów - prostoząbka taurydzkiego Orthodicranum tauricum (Sapjegin) Smirnova i krzywoszczeci przywłoki Campylopus introflexus (Hedw.) Brid. na Wyżynie Małopolskiej. - Naturalia 2: 119-123.

Plášek V . (2013): Mszaki w lasach. Przewodnik terenowy dla leśników i taksatorów. CLIP, Warszawa.

Stebel A. \& Ochyra R. (2008): Bryophytes of the Polish Carpathians. Sorus, Poznań.

- (2011): Chorological Studies on Polish Carpathian Bryophyte. Sorus, Poznań.

Stebel A., Rosadziński S., Wolski G.J., Staniaszek-Kik M., Fundali E., Armata L. \& Szczepański M. (2012): Further spreading of Orthodicranum tauricum (Bryophyta, Dicrananceae) in Poland. Botanika Steciana, Roczniki Akademii Rolniczej w Poznaniu CCCXCI: 75-79.

Sawicki J., Pisarek W. \& Szczecińska M. (2013): Mchy i wątrobowce Ostoi Napiwodzko - Ramuckiej. Przewodnik do warsztatów terenowych 56. Zjazdu PTB, Olsztyn, pp. 115-123,

Author's address: Jarosław Chmielewski, Department of Botany and Nature Protection, University of Warmia and Mazury in Olsztyn, Plac Łodzki 1, 10-727 Olsztyn, Poland.

Email: j.chmielewski90@gmail.com. 